\title{
貯蔵青果物の品質変化に関する生化学的研究
}

\author{
（第 4 報） 低温障害バナナ果実の $20^{\circ} \mathrm{C}$ 昇温眝蔵に伴う \\ gluconeogenesis $\prec$ amylolysis
}

\author{
能岡浄* \\ Biochemical Studies on Changes in Quality of Post-harvest \\ Fruits during Storage
}

Part IV. Changes in gluconeogenesis and amylolysis during after-ripening in chilling-injured banana fruit

\section{KIYOSHI YosHIOKA}

\begin{abstract}
Changes in starch and sugar contents and in enzyme activities related to gluconeogenesis and amylolysis during the process of after-ripening in chilling-injured banana fruits were compared with those of healthy fruit.

In the healthy fruits, a linear increase in sugar contents and a sharp decline of starch contents-started on the 6 th day of storage at $20^{\circ} \mathrm{C}$, accompanying with increase in phosphofructokinase (PFK) activity. While apparent fructose-1,6-diphosphatase (F1,6 DPase) activity stayed relatively low and constant level.

In contrast, a gradual increase in sugar contents accompanying with a remarkable increase in apparent F1, $6 \mathrm{DPase}$ activity but no significant change in starch contents were noted in the fruits stored at $6^{\circ} \mathrm{C}$.

Storage at $20^{\circ} \mathrm{C}$ after the storage at $6^{\circ} \mathrm{C}$ for 9 days caused a rapid increase in sugar contents and sharp decline of stach contents within 5 days. In these chilling-injured fruits, however, a low PFK activity and a remarkably high apparent F1,6DPase activity were noted throughout after-ripening.

These findings suggested that, in chilling-injured fruits, an increase in gluconeogenesis occurred preceding to after-ripening and an increase in amylolysis also occurred during the process of after-ripening.

(Received Apr. 24, 1973)
\end{abstract}

第3 報1において，緑熟ぐナナ果実を $6^{\circ} \mathrm{C}$ に貯蔵した 場合および $6^{\circ} \mathrm{C} に 9$ 日間置いた後 $20^{\circ} \mathrm{C}$ に昇温貯藏した 場合の障害果と, $20^{\circ} \mathrm{C}$ に貯蔵した果実 (対照区)につい て, アスパラギン酸およびセリンの代謝変化を比較し, 低温障害果の gluconeogenesis に関連する代謝経路を 検討した。

今回はさらにデンプン，僈元糖および非還元榶量の変 化ならびに糖の代謝に関連する酥素活性の変化を比較し て，低温障害バナナ果実の gluconeogenesis および amylolysis 亿関連する代謝経路を考察したので，その 概要を報告する。

\section{実 験 方 法}

\section{1. 実験材料}

試料はフィリッピン産の緑熟バナナ果実 (Del Monte) を神戸港入荷直後に，加工業者から購入した。

\section{2. 試 薬}

グルコースー6-リン酸 (G6P) ソーダ塩, フルクトース -6-リン酸 (F6P) ソーダ塩, フルクトース-1, 6-2 リン 酸 (F1, 6DP) 4-シクロへキシルフンモニウム塩, aldolase (ALD), triose isomerase (TIM), glycerate dehydrogenase (GDH) (以上 Boehringer); Anthrone,

* 大阪府立公采街生学院 栄養部（大阪市住吉区大領町 3 丁目 3)

Department of Nutrition Science, Public Health School of Osaka Prefecture. Sumiyoshi-ku, Osaka. 
グリシン(以上和光); ATP ンーダ塩(協和発酵); NADH (Oriental) はすべて市販品を用いた。

\section{3. 実験方法}

試料の貯蔵条件は前報1)と全く同様にし，以下の項目 に分けて比較実験を行なった。

(1) 還元糖，非還元糖およびデンプンの定量

果実を輪切りにし，無傷の果皮のついた試料約 $5 \mathrm{~g} に$ 6 倍量 (v/w) の $80 \%$ エタノールを加えて磨碎し, この ホモジネイトを沸騰水中で煮沸した。これを $8,000 \times \mathrm{g}$ で 10 分間遠心分蜼後，残查を $30 \mathrm{~m} l$ の $80 \%$ 熱フルコ 一ルで洗浄し，遠心分離する。残查の洗浄を 2 回くり返 し,これら上澄液を集め, 水を加えて定容とし還元糖お よび非還元煻の定量に用いた。なおこのとき，被検液の フルコール含量は少なく，フルコールによる糖の発色防 害は認められなかった。

上述の抽出残查に $10 \mathrm{~m} l$ の水を加えて䚇拌し，さら に $52 \%$ の過塩素酸 (PCA) を $13 \mathrm{~m} l$ 加えて冷却しなが ら 15 分間㩇拌後, $15 \mathrm{~m} l$ の水を加えて $8,000 \times \mathrm{g}$ で 10 分間遠心分離寸る。残查に $5 \mathrm{~m} l$ の水を加元て，さらに $52 \% \mathrm{PCA} 6.5 \mathrm{~m} l$ 加え, 以下同様に処理する。この 操作を 3 回くり返し，これら上登液を集め，水を加えて 定容とし，デンプンの定量に用いた2)。

(1) 還元糖の定量

上述の $80 \%$ フルコール抽出液の一定量を SoMOGYINELSON 法に従い, 545 nm で比色定量し ${ }^{8 / 4)}$ ，グルコー スに換算して表わした。

(口) 非還元糖の定量

(1)と同じ抽出液の一定量に塩酸を加えて，1/30 N の 塩酸溶液とし, 沸騰水中で 30 分間加水分解した。冷却 後水酸化ナトリウムで中和し，定容後その一定量を(1)と 同様にして比色定量し，加水分解前後の還元糖量の差に 0.95 を掛け,ショ糖に換算して表わした。

(N) デンプンの定量

上述の PCA 抽出液の一定量に, 冷却しながら Anthrone 試薬 $(0.2 \%$ Anthrone 裖硫酸溶液) $10 \mathrm{ml}$ を加え て撜拌後，沸腾水中で 7.5 分間加熱する。反応後ただち に流水中で泠却し，630 nm で比色定量した2)。

なおデンブン量は，同じ方法で得られるグルコ一ス標 準曲線からの值に 0.9 を掛仔て算出した。

(2) 酥素活性の測定

(1) 䤃素液の調製

果実を輪切りにし，無傷の果皮の着いた試料約 $15 \mathrm{~g}$ K $0.05 M$-triethanolamine 塩酸緩衝液 [pH 7.3; $10 \%$ $(\mathrm{v} / \mathrm{v})$ polyethylene glycol $400,1 \%(\mathrm{w} / \mathrm{w}) 2$-mercap- toethanol および $10 \mathrm{~m} M$-EDTA を含む〕約 2 倍量 (v/w) 加えて磨砕する。ガーゼで沪過後 $1,000 \times g$ で 15 分間遠心分離し，得られた上澄液を醉素液とした。 なおこれらの操作はすずて 0〜 5 C で行なった。

(a) 醉素活性の測定

(i) 見かけの glucose-6-phosphatase (G6 Pase) 活 性の測定

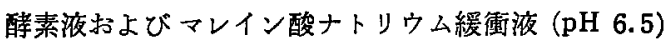
$30 \mu$ mole $儿$ 基質 G6P $10 \mu$ mole 加光て, 反応液の 全容量を $2.1 \mathrm{~m} l$ とし ${ }^{5)}$ ，次式により生成する $\mathrm{Pi}$ を定量 した。

$$
\mathrm{G} 6 \mathrm{P}+\mathrm{H}_{2} \mathrm{O} \rightarrow \mathrm{Glucose}+\mathrm{Pi}
$$

(ii) 見加けの fructose-1, 6-diphosphatase (F1,6 DPase）活性の測定

反応液は醉素液, グリシン一 $\mathrm{KOH}$ 緩衝液 ( $\mathrm{pH} 9.5)$ $100 \mu$ mole および $\mathrm{MgCl}_{2} 5 \mu$ mole $\mathrm{k}$ ，基質として F1,6 DP $5 \mu$ mole 加えて全容量を $2.2 \mathrm{~m} l$ とした6!。

なおこのとき生成物の F6P が基質となり fructose6-phosphatase (F6Pase) 活性も関与してくるので, こ れを考虑して F1,6DPase の場合と同じ反応条件で， 基質 F1, 6DP の代りに F6P $5 \mu$ mole 加光て, F6Pase により生成するPi を別に測定し，補正した。

$$
\begin{aligned}
& \mathrm{F} 1,6 \mathrm{DP}+\mathrm{H}_{2} \mathrm{O} \rightarrow \mathrm{F} 6 \mathrm{P}+\mathrm{Pi} \\
& \left(\mathrm{F} 6 \mathrm{P}+\mathrm{H}_{2} \mathrm{O} \rightarrow \text { Fructose }+\mathrm{Pi}\right) .
\end{aligned}
$$

以上 (i) (iii) において 3 分間のプレインキュベイシ ョン後, 反応液に基質を添加して各反忘を開始させ， $30^{\circ} \mathrm{C}$ で 10 分間振とうした。なおプランクには反応液か ら基質のみを除いたものを用いた。

$60 \%$ の PCA $0.2 \mathrm{ml}$ を加えて反応を止め，10 分間水 冷後遠心分㒧し, 上澄液について各反応式に従って生成 する $\mathrm{Pi}$ 量を FISKE らの方法により $660 \mathrm{~nm}$ で比色定量 しだ。

また反応停止後の非醉索的な基質の加水分解流よる Pi の混入を防ぐため, PCA の添加直後にブランクにむ 反応液之等量の基質をそれぞれ加えて，それ以後の条件 を全く同様にし，Pi の生成量の差を算出することによ り各醳素の活性を表わした。

なお 5 分間インキュベイショシしたときのそれぞれの 反応系における $\mathrm{Pi}$ 生成量は, 10 分間インキュベイショ

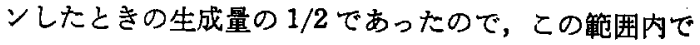
は Pi の生成量と酵素活性の間には直線的関你が成立す る。

また糖および Pi の比色定量は，日立製分光光度計 181 型により光路幅 $1 \mathrm{~cm}$ のキュベットを用いて，各波 
長での吸光度から測定した。

(iii) phosphof ructokinase (PFK) 活性の測定 反応液は酵素液，フンモニウムーリン酸緩衝 液 $(\mathrm{pH}$ 7.6) $10 \mu$ mole, ATP $4.5 \mu$ mole, $\mathrm{MgCl}_{2} 10 \mu$ mole, $\mathrm{NADH} 0.4 \mu$ mole, ALD 1.4 unit, TIM 4.0 unit お よび GDH 1.0 unit に, 基質 F6P 孛 $10 \mu$ mole 加えて 全容量を $2.0 \mathrm{~m} l$ とした ${ }^{8)}$ 。

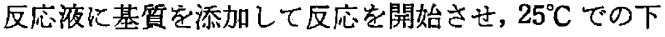
式に従って減少する $\mathrm{NADH}$ を前報”と同じ方法で測定 することにより活性を算出した。

$$
\begin{gathered}
\mathrm{F} 6 \mathrm{P}+\mathrm{ATP} \rightarrow \mathrm{F} 1,6 \mathrm{DP} \text { ALD } \\
-\mid \begin{array}{c}
\rightarrow \text { Glyceraldehyde-3-phosphate } \\
\downarrow \text { TIM }
\end{array} \\
\rightarrow \text { Dihydroxyacetonephosphate }
\end{gathered}
$$

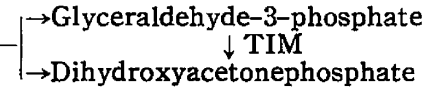

Dihydroxyacetonephosphate+NADH GDH

$\rightarrow$ Glycerate-3-phosphate $+\mathrm{NAD}^{+}$

\section{実 験 結 果}

緑熟健全バナナ果実のデンプン含量が貯蔵条件により いかに変化し，またそれに関連して還元糖および非還元 糖がどのように変北するのかを調べて，デンプンの减少 と糖，すなわち還元糖と非票元糖の総量变化を図示した のが Fig. 1-A であり，各果実における還元糖と非還元 糖の含量を図示したのが Fig. 1-B である。

Fig. 1-A において， $20^{\circ} \mathrm{C}$ に貯蔵した果実(対照区)て は4 日目までデンプンおよび糖はほとんど変化しない。 6 日および 8 日目にデンプンは直線的に急減し，これに 見合うような糖の著しい増加が認められる。10日目以後 デンプンはほとえど消失しているが，糖は增加する。な お Fig. 1-Bより，この時期の糖の増加はおもに還元糖 の急増に基うくことがわかる。

これに対し $6^{\circ} \mathrm{C}$ 貯蔵した果実では，4 日目は対照区 とあまり変らないが，6日および9日目ではデンプンの 減少がほとえど見られないのに䌅は増加している。この 場合の糖の增加は Fig. 1-Bより；主に非還宅糖の増加 に基うく。

$6^{\circ} \mathrm{C}$ に 9 日間貯蔵した果実を $20^{\circ} \mathrm{C}$ に昇温すると，1 日 目では昇温前と大差ないが， 3 日目にはデンプンは 1 日 目より䄪 $0.9 \mathrm{~g}$ 減少するのに対し, 糖は約 $2.1 \mathrm{~g}$ も増 加する。5 日および7日目になるとデンプンは著しく減 少し，その減少量に見合うだけの糖の増加が見られ，対 照区の 6 日および8 日目とよく似た傾向を示す。

プドウ糖合成に関連する見かけの G6Pase 活性孛調 ベたのが Fig. 2 である。
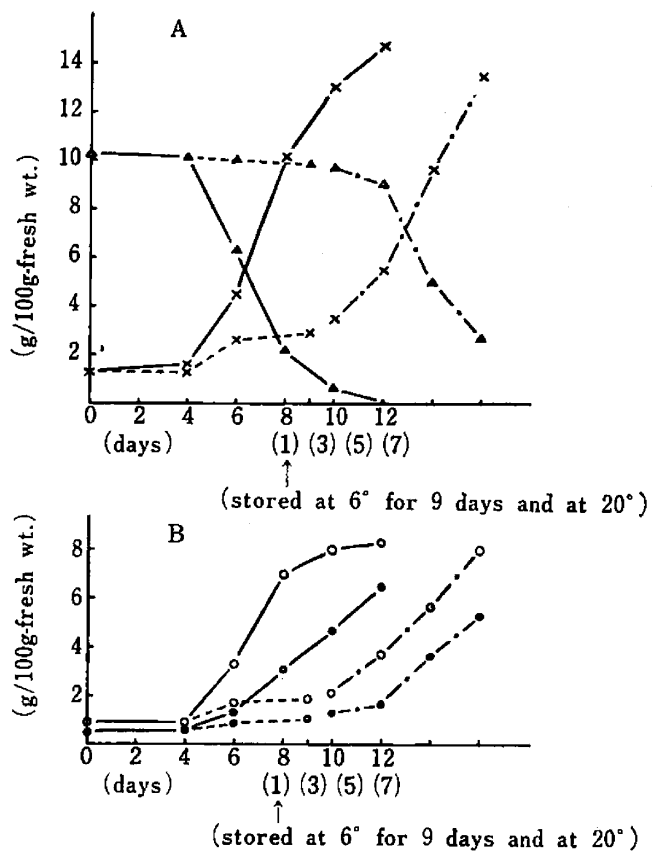

Fig. 1-A. Changes in starch and sugar contents in healthy and chilling-injured banana fruit.

Fig. 1-B. Changes in reducing land lnonreducing sugar contents in healthy and chilling-injured banana fruit.

A starch contents,

$x$ total sugar contents, the sum of reducing and

nonreducing sugar contents

- reducing sugar contents

$O$ ronreducing sugar contents

- Control (at $20^{\circ} \mathrm{C}$ )

-... Chilling-injured fruit stored at $6^{\circ} \mathrm{C}$

- - Chilling-injured fruit stored at $6^{\circ} \mathrm{C}$ for 9 days and at $20^{\circ} \mathrm{C}$

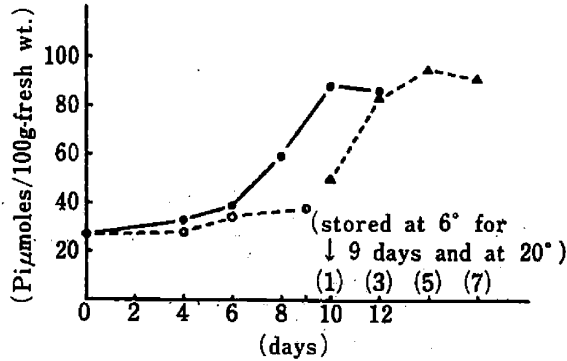

Fig. 2. Change in apparent glucose-6-phosphatase activity in healthy and chilling-injured banana fruit tissues.

- Control (at $20^{\circ} \mathrm{C}$ )

0 - $O$ Chilling-injured fruit stored at $6^{\circ} \mathrm{C}$

$\Delta \cdots$ Chilling-injured fruit stored at $6^{\circ} \mathrm{C}$ for 9 days and at $20^{\circ} \mathrm{C}$ 
対照区では 6 日目まで貯蔵日数とともに徐々に増加 し，8日および 10 日目にはほぼ直線的に急増し，以後 わずかに減少する。

これに対し $6^{\circ} \mathrm{C}$ に貯藏した果実において，4 日目では 対照区より活性は低く，以後少しずつ増加する。20 ${ }^{\circ} \mathrm{C} K$ 昇温後 1 日目ではさらに高くなり, 以後急増して 5 日目 には最大活性となるが，その後わずかに減少する。

次に glycolysis の key-enzyme の一つである PFK 活性を調べたのが Fig. 3 である。

対照区において 4 日目まで活性の増加はほ之えど見ら れないが, 以後直線的に急増して 8 日目には最大活性に なるが，その後は次第に減少する。

$6^{\circ} \mathrm{C}$ に貯蔵した果実において，4 日目では対照区とほ とえど変らないが，6日目には 2 倍に活性が壃加し，以

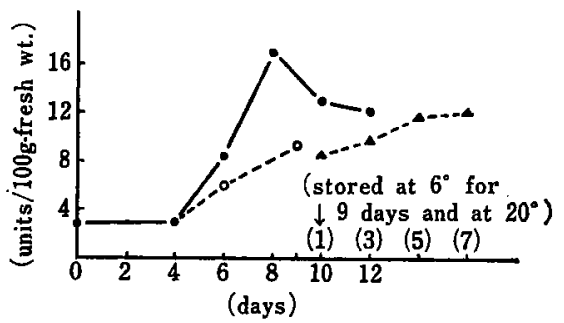

Fig. 3. Change in phosphofructokinase activity in healthy and chilling-injured fruit tissues.

- Control (at $20^{\circ} \mathrm{C}$ )

O--O Chilling-injured fruit stored at $6^{\circ} \mathrm{C}$

$\Delta--\Delta$ Chilling-injured fruit stored at $6^{\circ} \mathrm{C}$ for 9 days and at $20^{\circ} \mathrm{C}$

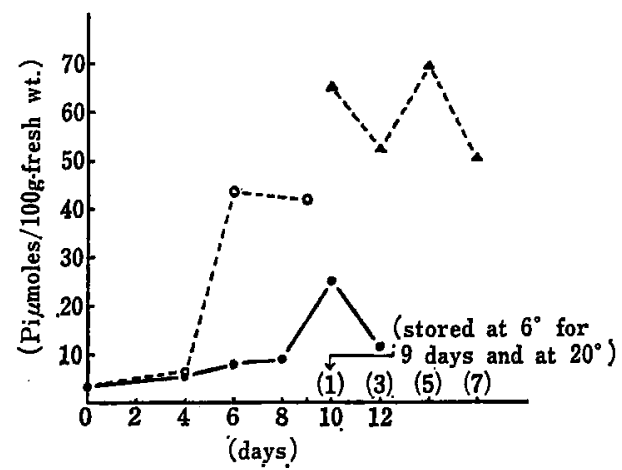

Fig. 4. Change in apparent fructose- 1, 6-diphosphatase activity in healthy and chillinginjured banana fruit tissues.

- Control (at $20^{\circ} \mathrm{C}$ )

$0 .-0$ Chilling-injured fruit stored at $6^{\circ} \mathrm{C}$

$\Delta \cdot \Delta$ Chilling-injured fruit stored at $6^{\circ} \mathrm{C}$ fir 9 days and at $20^{\circ} \mathrm{C}$
後さらに増加するが，対照区よりはかなり低い。20ㄷ 昇温すると 1 日目には昇温前と同程度の活性を示し，そ れ以後は日数とともに徐ヶに増加するが，対照区の最大 活性よりはかなり低い。

これに対し gluconeogenesis $の$ key-enzyme の一つ である見かけの F1,6 DPase 活性を調べたのがFig. 4 である。

対照区では 8 日目まで貯蔵日数とともに徐々に増加 し，10 日目には約 3 倍に急増するが，12 日目には半減 する。

$6^{\circ} \mathrm{C}$ に貯蔵した果実において，4 日目では対照区と大 差ないが，6日目には急増して対照区の約 6 倍の值を示 し，以後も活性はあまり变らない。 $20^{\circ} \mathrm{C}$ に昇温後 1 日目 で活性はさらに增加し，3 日目には減少するが，5 日目 には再び増加して対照区の最大活性の約 3 倍となる。

\section{考察}

対照区において 6 日および 8 日目ではデンプンの減少 量に見合うだけの糖の増加が認められ，「追熟に伴って， デップンの分解により糖が増加する」という邨田らの報 告 ${ }^{101}$ と一致する。また PFK 活性もほぼ直線的に急増 し，追熟に伴って glycolysis が盛んになることが推察 される。特に 8 日目では第 2 報 $^{9}$ において， pyruvate decarboxylase および alcohol dehydrogenase 活性の 著しい堌加に伴っててルコールが生成され, isocitrate dehydrogenase および glucose-6-phosphate dehydro* genase 活性も増加するため $\mathrm{CO}_{2}$ 排出が盛んとなり，い わゆる climacteric rise の現象が起るものと考察した が,これを裏づけるように，ての時期にはデンプンの減 少が著しく, PFK は最大活性となる。また 8 日目以後 還元糖は直線的に急增し，それに見合うように見かけの G6Pase 活性む10日目まで急堌する。

10 日目以後の対照区ではデンプン含量は著しく低下 し，デンプンが減少する割合も低下するが，それ以上に 糖が堌加する。また PFK 活性は8 日目に比べて低下す るが，見かけの G6Pase および F1，6DPase 活性注高 くなる。しかるに第1報11において，7日目の対照区に 多量含まれていたセリンが 13 日目になると急減し，ま た第3 報!!たおいて，10日目の対照区では ${ }^{14} \mathrm{C}$ 一リンの 糖区分への取込みは，有機酸への取込み量の $138 \%$ と他 の時期に比べて多いことを報告した。

これらのことから，10日目以後の対照区での過熟化に 伴う糖の増加見象は，それ以前に多量蓄積されていたセ リンが糖へ転換した結果に基つくくすの考えられる。 
A.

(stored at $6^{\circ} \mathrm{C}$ for 6 to 9 days, and then at $20^{\circ} \mathrm{C}$ for 1 to 3 days)

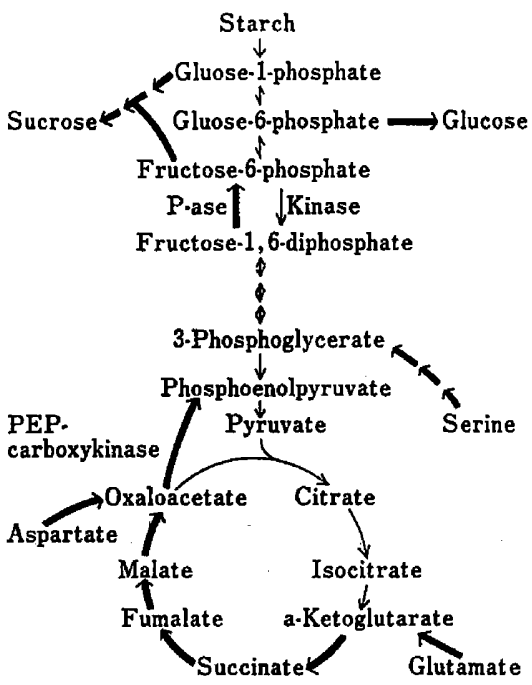

B.

(stored at $6^{\circ} \mathrm{C}$ for 9 days and at $20^{\circ} \mathrm{C}$ for 5 to 7 days)

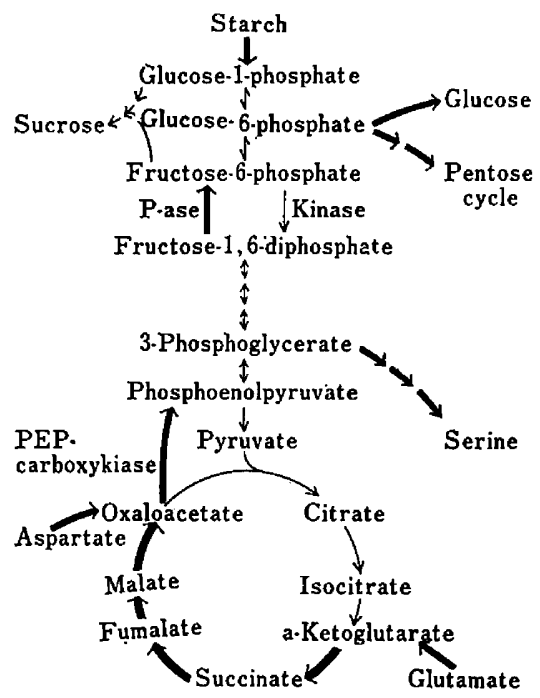

Fig. 5. Changes of metabolic carbon path in chilling-injured banana fruits

$6^{\circ} \mathrm{C}$ に貯藏した果実において，4日目では対照区と大 差ないが，6日と 9 日目の果実および $6^{\circ} \mathrm{C} に 9$ 日間置い た後 $20^{\circ} \mathrm{C}$ に昇温して 1 日拈よび 3 日目の果実では, デ ンプンはほとえど減少しないが, それ以上に糖, 特に非 還元桾の増加が認められる。また見かけの F 1,6DPase 活性注対照区の 5〜9 倍も高い。しかるに第3 報”にお

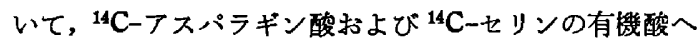
の取込みに対する糖への取込みの割合は，対照区よりも 著しく高いことを報告した。

これらの事実から $6^{\circ} \mathrm{C} に 6 〜 9$ 日間貯蔵した果実预よ び $20^{\circ} \mathrm{C}$ に昇温後 $1 \sim 3$ 日の果実では, アスパラギン酸 およびセリンなどのアミノ酸が Fig. 5-A の太字の矢印 のように糖へ転換してゆく割合，すなわちgluconeogenesis が対照区に比べて著しく高いものと推定できる。

$6^{\circ} \mathrm{C}$ に 9 日間貯蔵した果実を $20^{\circ} \mathrm{C}$ に昇温すると 5 日 および7日目にはデンプンが著しく減少し，この減少量 に見合うだけの糖の増加が認められ，対照区の6日およ び8日目と同じような傾向を示す。しかし対照区の 8 日 目より PFK 活性はかなり低く，見かけの F 1,6DPase 活性は著しく高い。しかるに第 2 報" 5〜7 日目の phosphoenolpyruvate (PEP)-carboxykinase 活性は 他の果実に比べて著しく高く，また第 3

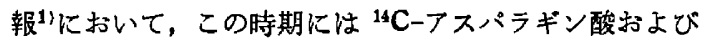
${ }^{14} \mathrm{C}$ 一リンの有機酸への取込みに対する糖への取込みの

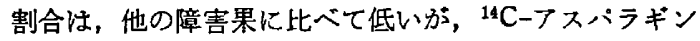
酸の pentose および hexose への取込死洋逆に多いこ とを報告した。

以上の事実を考え合わせると, 昇温後 5〜7 日の果実 では Fig. 5-B の太字の矢印のように, 昇温前の gluconeogenesis が引き続き盛えであると同時に，これらの 果実における糖の急増は主にデンプンの分解に基ゔくる のと考えられる。またその糖が glycolysis によりさら に分解されてゆく割合は，対照区の8 日目に比べてかな り低く，いわゆる amylolysis が盛えであると思われ る。

なお本論文での G6Pase および F1,6DPase の両酵 素活性は見かけ上の活性であり，本醳素そのものの活性 以外に基質範囲の広い phosphatase 活性が関与してい る可能性がある。今後この点については，より詳細に検 討して行きたい。

要 約

フィリッピン産の緑熟健全パナナ果実を $6^{\circ} \mathrm{C}$ に貯蔵し たもの， $6^{\circ} \mathrm{C}$ に 9 日間置いた後 $20^{\circ} \mathrm{C}$ に昇温貯蔵したも のおよび $20^{\circ} \mathrm{C}$ に貯蔵した果実(対照区)についてデンブ ン, 還元糖および非還元糖の変化と，見かけの G6Pase, PFK および見かけの F1,6DPase 活性の变化を調べて 次の結果を得た。 
対照区において，4 日目までは初めとほとえど変らな いが，6日および8日目になるとデンブンが著しく減少 しそれに見合うだけの糖の急增が認められ，同時に PFK 活性も急增する。また 8 日目以後僈元糖が急增し， 見かけの G6Pase 活性む 8 10 日目まで直線的に急增 する。10 日目以後デンプンはほとんど含まれなくなり， PFK 活性は次第に減少するが，見かけの G6Pase 活性 は急增し，糖はさらに增加する。見かけの F1,6DPase 活性は貯蔵日数とともに少しずつ増加し，10日目には約 3 倍に急增するが, 以後半減する。

$6^{\circ} \mathrm{C}$ に 4 日間貯蔵した果実は対照区と大差ないが， 6 日および 9 日間貯藏した果実および $6^{\circ} \mathrm{C} に 9$ 日間置いた 後 $20^{\circ} \mathrm{C}$ に昇温すると 1 日小よび 3 日目では, デンプン の減少はほとんど認められないが，それ以上に糖，特に 非還元煻が増加する。また見かけの G6Pase および PFK 活性は対照区よりも低いが，見かけのF1，6DPase 活性著しく高い。

$6^{\circ} \mathrm{C}$ に9 日間置いた後 $20^{\circ} \mathrm{C}$ 亿昇温して 5 日および 7 日目の果実ではデンプンが急隇し，それに見合うような 糖の著しい増加が認められ，対照区の6日标よび8日目 と同じような傾向定す。しかし醳素レベルで対照区の 8 日目と比較すると, 見かけの G6Pase 活性は高いが, PFK 活性はかなり低い。いっぽう見かけの F1,6DPase
活性は著しく高い。

以上の結果に基ゔき，糖の代謝経路を考察した。 おかりに本実験遂行にあたり，種々御討議いただいた 大阪府立大学農学部生物化学研究室の皆様に感謝いたし ます。

\section{文献}

1) 能岡 浄: 食品工誌, 20 (10), 456 (1973).

2) $\mathrm{MCC}_{\mathrm{READY}}$, R.M., et al.: Anal, Chem., 22, 1156 (1950).

3) Sомоgri, M.: J. Biol. Chem., 195, 19 (1955).

4) Nelson, N.: J. Biol. Chem., 153, 375 (1944).

5) Swanson, M.A.: J. Biol. Chem., 184, 647 (1950).

6) Pogeld, B.M., et al.: J. Biol. Chem., 208, 149 (1954).

7) FIske, G. H., et al.: J. Biol. Chem., 66, 375 (1925).

8) Lindelt, T.J., et al.: J. Biol. Chem., 243, 907 (1968).

9）能岡 浄・本田幸一郎：食品工誌, 19 (4), 131 (1972).

10）邨田卓夫・古 衡山・緒方邦安：食品工誌, 12 (4), 121 (1965).

11）能岡 浄・本田幸一郎：食品工誌, 17, (11), 489 (1970). 